\title{
Household extension and employment among Asian immigrant women in the US
}

\author{
By \\ Jeehye Kang \\ Philip N. Cohen \\ University of Maryland, College Park \\ Published in Journal of Family Issues online before print September 21, 2015 \\ doi: $10.1177 / 0192513 \times 15606489$
}

\begin{abstract}
To help explain variation in Asian immigrant women's employment, we examine the association between women's employment and the presence and characteristics of adult extended household members for seven Asian immigrant groups: Chinese, Korean, Asian Indian, Pakistani, Filipina, Vietnamese, and Japanese. Using the American Community Survey 2009-2011 pooled data, we find that married, first generation Asian immigrant women's employment rates are higher when they live with parents or parents-in-law. Further, hampered by housework and care work, these women apparently receive some support in particular from female extended adults providing child care assistance - especially in families with young children. On the other hand, we find a negative association between the presence of disabled adults only for Koreans, and employed extended adults' support varies across nationality groups. Variations in each of these dynamics across Asian groups suggest the need for further study.
\end{abstract}

\section{Introduction}

Asian immigrant women's employment patterns display variation across ethnic groups which have yet to be explained. Heterogeneity in social class, income, and demographic profiles within Asian immigrants partly explain these inequalities (e.g. Allard 2011; Espiritu 2008; Espiritu 1999; Cohen and Read 2007; Ishii-Kuntz 2000; Read 2004; Wong and Hirschman 1983; Yamanaka and McClelland 1994), which may be due to immigration policies differentially selecting demographic groups from different nationalities (Chow 1994: 206). While many Filipino women came as nurses, for example (Choy 2003), most Asian immigrant women came for family reunification or as spouse dependents of skilled labor migrants (Raj and Silverman 2002). On the other hand, Vietnamese immigrant women, who mostly came to the U.S. as refugees, have high employment rates for economic reasons, although they occupy the lowest paying jobs (Le 2007). However, immigrant women's diverse employment needs and constraints may be understood in relation to traditional family roles to the extent that such family systems persist (Espiritu 2008: 95). Thus, Asian immigrant women's employment reflects their gender and family roles within patriarehat family systems as well as economic constraints and opportunities. And studying how diverse family characteristics affect national origin groups differently offers insight into Asian immigrant women's employment disparities.
We are particularly interested in extended families, which are the product of a combination of economic, demographic, and cultural forces (Cohen and Casper 2002; Kamo 2000; Kamo and Zhou 1994; Rosenbaum and Gilbertson 1995). As a strategy to cope with economic difficulty, the needs of older relatives, or a culturally prescribed practice among Asian Americans, family extension reorganizes family roles and behaviors. Women's labor market participation must be negotiated within this arrangement. We examine how extended household members may support or hinder Asian women's employment. Although previous research suggests an important role of household extension for women's employment (e.g., Cohen 2002), the nature of this influence, and its variability, are less understood. Our research will help explain how such family dynamics influence women's market labor participation, with emphasis on an under-studied group: Asian first-generation immigrant women. In light of persisting differentials in labor force participation among immigrant women and the prevalence of extended family living arrangements among immigrant families in the U.S, these insights into immigrant women's labor market behavior provide a useful advance on existing research.

We next discuss explanations for the labor force participation of immigrant women and the economic, demographic, and cultural implications of household extension, then we outline our data and models. The 
probability of Asian immigrant women's employment within extended household is modeled, controlling for their personal endowments, material and family circumstances, and labor market characteristics. We conclude with a discussion of what Asian immigrant women encounter in their adaptation to U.S. society across ethnic, familial, and local labor market contexts.

\section{Labor Force Participation of Immigrant Women}

Individual resources, local labor market conditions, and family conditions are conventionally used to predict immigrants' employment decisions. We highlight the limitations of the human capital model, then review previous research on the effects of conventional family conditions (such as husbands' income and presence of young child) on women's employment decision. This is followed by theoretical links between extended households and women's employment, and empirical findings. Focusing on ethnic variations in economic, demographic, and cultural backgrounds among Asian immigrant families, we consider the different family roles of extended members by gender, employment, and health status and how they are associated with women's employment decisions across ethnic groups.

\section{Individual Resources}

Individual resources such as education, length of residence, and English proficiency are positively associated with immigrant women's labor force participation. Human capital theory suggests that women with adequate education and job skills are more likely to enter employment compared to those with lower levels of these resources (Cohen and Bianchi 1999; Haines 1987). Education also accounts for a substantial part of group differences in employment between White, Black, and Latina women (England et al. 2004). For immigrants, duration of residence is an important precursor of knowledge and resources needed to function in the labor market of the host country, including language skills as well as formal credentials and licenses. For those from more traditional societies, longer duration increases women's exposure to social norms regarding dual-earner roles (Schoeni 1998; Yamanaka and McClelland 1994; but see Long 1980). These factors may influence both the ability to get a job and the potential wages offered, which in turn affect immigrant employment rates.

Recent studies find these conventional explanations are less applicable for the experiences of some ethnic groups of women (Light and Gold 2000; Read 2004). For example, female immigrants from certain countries (e.g. Japan, India, Iran) are not as able to convert their education into higher occupational status, compared with male immigrants (Waldinger and Gilbertson 1994). More recently, Asian Indian and Korean women have been shown to have much lower employment rates than their high levels of education would otherwise predict (Cohen and Read 2007). Clearly, factors other than human capital affect Asian immigrant women's employment deci- sions or opportunities.

\section{Family Conditions}

Economic resources available to the household, and the composition of the household, all affect women's employment. Husbands' income generally reduces the labor supply of wives (Becker 1965; Berk 1985: 201; Brekke et al. 2013). However, this effect that declined from the 1970s to the 1990s (Cohen and Bianchi 1999), and among White, Black, and Hispanic immigrant women England and colleagues (2004) found trivial effects of husband's income in deterring women's employment. Whether these patterns hold for Asian immigrant women is unknown.

The presence and greater number of children lowers women's employment, among both married and single mothers (Cohen and Bianchi 1999; Tienda and Glass 1985). Because mothers are generally more responsible for child care than are fathers, access to childcare to replace their own services is important for employment. Children therefore increase the potential wage required to make employment pay off (Herbst 2010). Although the downward pressure that children exert on mothers' labor supply has decreased over time, the effect remains substantial (Juhn and Potter 2006; Leibowitz and Klerman 1995).

Family-oriented small businesses also affect women's employment. Given immigrants' reliance on family labor (Sanders and Nee 1996), immigrant women are more likely to be self-employed or family workers. Women's endeavors in family-run businesses (Dallalfar 1994), as well as their crucial roles in the family business of men (Anthias and Mehta 2003), have been recognized as important economic strategies for immigrant families' upward mobility. On the other hand, some argue that women's labor in family businesses - as an extension of their household tasks - reinforces patriarchal ideology (Espiritu 2008: 85).

\section{Extended family}

The effects of family extension on women's employment decisions remain understudied. Extended family households, which consist of family members other than the householder parents and their children (Kamo 2000; Angel and Tienda 1982), include two types, depending on the generational relations among adult individuals: horizontally extended households and vertically extended households. The former include family members "from the same generation and age groups or other related lines," such as brothers, sisters, and cousins (Glick, Bean, and Van Hook 1997; see Ruggles, 1987). Vertically extended households include adults from "several points in the life course," such as parents, grandparents and grandchildren. Prior research documents substantial differences in the motivations of those forming vertical and horizontal extended households (Van Hook and Glick 2007; Glick et al. 1997), and Asian Americans are found to be more likely to live in vertical- 
ly extended households (Kamo 2000). For extended households, researchers have not resolved to what extent - and in what contexts - additional family members take care of family responsibilities for women versus adding extra household labor burdens for them. Theoretical links between extended family structure and immigrant women's employment can be divided into three categories: economic, demographic, and cultural.

From the economic perspective, the economic hardship among immigrants, especially newly arriving immigrant families, is the most important factor that leads to family extension (Angel and Tienda 1982; Van Hook and Glick 2007; Harrison et al. 1990; Hemmens, Hoch, and Carp 1996). For example, economic necessity has driven immigrants from South Asian countries such as India, Pakistan, Bangladesh, and Sri Lanka to extended households (Ram and Wong 1994). Family extension has been documented as an important survival strategy for low-income people to pool limited resources and resolve child care needs (Edin and Lein 1997), and some research shows that extended adult members' help provide child care and housework (Tienda and Glass 1985; Treas and Mazumdar 2002, 2004). Such grandparents do the cooking, cleaning and babysitting that helps permit dual earner couples, or single mothers, to improve their job prospects (Min 1998; Treas 2009; Treas and Mazumdar 2002; 2004). These findings mainly came from vertically extended families, and although less is known about horizontally extended families, some theory predicts that larger families encourage women's labor force participation by increasing income needs for a given level of consumption (Becker 1965; Tienda and Glass 1985).

The demographic profile of elderly Asian Americans implies increased demands for care within families. Asian Americans over age 65 accounted for 3.3\% (1.3 million) of the older population in 2007 (Weng, and Nguyen 2011: 329; United States Department of Health and Human Services 2009), and their population is projected to grow faster than the total Asian population (Mui 2006: 194; see Choi 2001). A great majority of Asian American elders are foreign-born, having migrated as older adults (Mui 2006). More than 85 percent of Vietnamese, Filipino, Korean, Asian Indians and Chinese elders (over age 65) were foreign-born immigrants (Weng, Nguyen 2011; see Mui and Shibusawa 2008). Because Asian American elders' primary reason to migrate is family reunification (Mui2006), and their high rate of coresidence with adult children (Ishii-Kuntz 2000), their role in Asian women's employment decision in intergenerational households may be considerable.

The extended family structure may or may not be a cultural embodiment of dominant "traditional" family values among ethnic immigrants (Fernández and Fogli 2009), yet the prevalence of intergenerational coresidence among Asian Americans is often described as a culturally-specific expression of filial piety (IshiiKuntz 2000). In the U.K., for example, extended families are important for Pakistani and Bangladesh immigrants to connect with Islamic communities that reflect kinship commitment (Ansari 2004; Crozier and Davies 2006). Vertical extension in particular is consistent with an "elder-respecting" value among Asian Indians who live in extended households (Kalavar and Van Wiligen 2005: 227). When it comes to the first generation immigrant families, family life is heavily influenced by ethnic and national traditions. To that extent we expect that women's employment in extended families will be more influenced by "traditional" gender roles. However, specific cultural prescripts surrounding life events may differ by ethnicity. Although the traditional norms are universally documented in South Asian (Banerjee 2013; Salway 2007), South-East Asian (Kibria 1999; 2008), East Asian (Ishii-Kuntz 2000; Kamo 1994; Min 2001) immigrant studies, the specificity of cultural practices vary.

Thus, we expect that the relationship between household extension and women's employment decisions will differ according to the economic, demographic, and cultural backgrounds of Asian immigrant families. In particular, extended members' gender, employment status, and health status should be important factors in determining their family roles and contributions. First, women are much more likely to care for young children. Previous research has focused on grandmothers' support for their adult daughters (Wilson 1986; see Slaughter and Dilworth-Anderson, 1985). However, to the best of our knowledge, there has been no research on whether female extended adults' support for women varies by racial-ethnic group.

Second, the effect of employed non-nuclear adults' roles on women's employment is largely positive (Cohen and Casper 2002; Figueroa and Melendez 1993; Hernandez 2007). Economically active members may help women's employment by contributing income for child care services (Cohen 2002, Jarrett 1994) or by generating employment contacts (Stoloff, Glanville, and Jayne 1999). On the other hand, additional income from employed household members may encourage women to stay home with their children instead of purchasing childcare services and working outside the home.

Considering many Asian immigrant workers' involvement in ethnic niches, employed member's provision of contacts would be subject to ethnic labor market structures (Eckstein and Nguyen 2011). Thus, the effect of employed members' job connections will differ depending on the ethnic context. In case of Chinese immigrants in New York, for example, employment contacts mostly are not useful to women because they are geared toward men's jobs and skills (Chin 2013; Zhou 1992). Network contact effects may further vary among Korean immigrants involved in apparel, accessory, grocery businesses; Vietnamese in hunting and fishing or nail salons; and Asian Indians in the motel management business (Eckstein and Nguyen 2011; Le 2007). Since no empirical research exists for employed extended household member effects on Asian immigrant women, we begin 
with the expectation that employed extended family members are more likely to help rather than hinder women's employment, then explore how the patterns vary by national-origin groups.

Finally, extended members' health status may determine their ability to work around the house versus their needs for assistance and support. Disabled older adults may lower women's labor force participation by increased in-home care demands. Or poor health may motivate elderly parents to join their children, who are expected to provide economic support (Kamo 2000). Women, perceived as primary caregivers (EspingAndersen 2009; Ridgeway 2011), may be expected to provide care for disabled adults rather than working outside the home. Again, ethnic factors are in play. Among elderly Korean immigrants, those who are highly committed to traditional collectivist values are less likely to look for formal assistance (Weng and Nguyen 2011: 331; see Lee and Eaton 2009). However, there has been no research on whether disabled extended adults' support for women varies across national-origin groups.

\section{Local labor market conditions}

Immigrant women's employment may be affected by local labor market conditions, including the level of ethnic concentration (Banerjee 2013; Chin 2013; Greenlees and Saenz 1999; Pedace and Kumar 2014; Sanders and Nee 1996), women's overall employment rates (Cotter, Hermsen, and Vanneman 2001), and local unemployment rates (Kahn and Whittington 1996). The evidence is mixed regarding ethnic variation. High ethnic concentration may allow immigrant women to use their native language and previous work experience to gain employment (Min 1997; Portes and Bach 1985). Particularly, a co-ethnic employer in a closely-knit ethnic enclave may provide informal help with childcare by allowing flexible work hours and environment (Banerjee 2013: 99). On the other hand, if good jobs in the enclave economy are reserved for men, as was the case in New York with Chinese immigrants (Zhou 1992), there might be no concentration advantage for women. Chin's more recent observation of the same group also points to unequal job opportunities for women (2013). Further, high ethnic concentration may strengthen the effect of traditional attitudes that discourage women's employment (Min 2001; Read 2004). For instance, Korean immigrants' economic segregation, and their affiliation with ethnic churches, perpetuates the patriarchal ideology that stresses husbands as primary family breadwinners and decision makers (Min 2001). With regard to unemployment rates, married immigrant women living in areas of higher unemployment are less likely to be employed (Cooke and Bailey 1996), a pattern also found for Latinas in particular (Kahn and Whittington 1996), suggesting the effect may vary across ethnic groups.

\section{Hypotheses}

Based on this review, we test a set of hypotheses on family support for or hindrance of women's employment by extended family members. We focus on extended family, specifically ethnic variations in the association between Asian immigrant women's employment and their extended family members' demographic and socioeconomic characteristics. From an economic perspective, women living with extended family overall are more able and motivated to generate income. More specifically, female extended adults - in this paper, mothers (in-laws) - are likely to provide householder women with child care and traditional housework support. Employed extended members should increase job opportunities for host women. And disabled extended adults likely increase the need for women's care work at home. Reflecting the various cultural and structural factors motivating family extension, and the differential socioeconomic positions among Asian immigrants, we also expect ethnic variations, as we will discuss.

We hypothesize:

1. A positive association between the presence of extended household members and women's employment.

1a. Ethnic variations in the association between the presence of extended household members and women's employment.

2. A positive association between the presence of female extended household members and women's employment;

2a. A positive interaction between the presence of children under age five and female extended household members on women's employment.

3. A positive association between the presence of employed extended household members and women's employment;

3a. Ethnic variation in the association between the presence of employed extended household members and women's employment;

4. A negative association between disabled extended household members and women's employment; and

4a. Ethnic variation in the association between disabled extended household members and women's employment.

\section{Data and Methods}

Using the American Community Survey, 20092011 pooled data, we analyze employment among married, foreign-born, Asian immigrant women, living in their own households, who immigrated at age 18 and older: Chinese, Asian Indian, Korean, Japanese, Filipina, Vietnamese, and Pakistani. Three years of data are pooled to increase the reliability of estimates of smaller groups in the sample. The 3-year files include approximately $3 \%$ of the population. 
We coded them into seven ethnic/nationality groups based on the Census "race" question - which in the Asian category presents a list of national origins instead of relying on country of birth. This prevents, for example, ethnic Chinese who were born in the Philippines from being counted as Filipina. We exclude those who immigrated as children - the 1.5 generation - to highlight patterns for those whose cultural orientation was established prior to immigration.

We include women ages 18-54, who are married and not attending school. In this age range women are in the economically active population, and they are both likely to have young children living in their homes - thus potentially needing childcare support - and to be hosting older extended household members. To capture these dynamics, we restrict the sample to those who are householders or spouses of the householder, thus excluding women who live in the homes of others. Such "guests," who live as extended household members in others' homes (Cohen and Casper 2002), enter the analysis as part of the context for employment that we seek to understand for householder women.

\section{Measures and models}

\section{Dependent Variables}

Immigrant women's current employment status specifies whether each woman was employed at least one hour for pay or profit during the reference period at the time of the interview. For example, current employment status in 2009 ACS sample indicates that whether a woman was employed during 2009 the reference period; in 2010 ACS sample, a woman was employed during 2010 , and so on. Thus, the 3-year files have three different reference period in each sample: the year of 2009, 2010, and 2011. Our models predict women's employment, coded dichotomously, using logistic regression. We use employment, rather than labor force participation (including those coded as unemployed), because the ACS, unlike a targeted labor force survey, is not specifically designed to differentiate between those who are unemployed versus out of the labor force (Read and Cohen 2007).

\section{Independent Variables}

The presence and gender, employment, and disability status of older extended adult members are explanatory variables. Older extended adults are narrowly defined as parents or parents-in-law of the householder/spouse women. Due to the prevalence of vertically extended households among Asian immigrant families, and greater heterogeneity in horizontal family extension, including such diverse members as younger nieces and older uncles, we focus on vertically extended family members. We code their gender, employment, and disability status with dummy variables. To identify the most pertinent disabilities for the question of care-intensive labor demands, we code as disabled those with reported self-care, ambulatory, or independent living disabilities. ${ }^{1}$

Individual factors include age, education, English ability, duration of U.S. residency, and disability. Age is measured as a continuous variable. Educational attainment (high school graduate, some college, four-year degree, advanced degree) is treated with dummy variables. English ability is measured with dummy variable indicating whether the women report speaking English "very well." We categorize duration of U.S. residency into 0-9 years, $10-19$ years, 20 or more years. These variables are most similar to those used by Cohen and Read (2007).

Family conditions include husband's income (logged) and any household income except the husbands' or wife's wages (also logged), the number of the householder's own children, the presence of children under age 5 , and whether any family member is self-employed (to capture the presence of a family business). We also control for the total number of adults in the household to isolate effects of older extended household members, who are only a subset of potential non-nuclear members.

Local labor market conditions include women's share of employment in the local metropolitan area, the local unemployment rate, and the degree of ethnic concentration in the local metropolitan area. Ethnic concentration indicates the density of the co-ethnic population in the local area relative to the national proportion of the population from the ethnic group (calculated as in Cohen and Read 2007).

\section{Models}

The probability of immigrant women's employment is estimated using logistic regression models. We use three models, each estimated separately for the different national origin groups. Model 1 includes all sampled women, with a variable indicating the presence of any vertically extended-family member, which allows examination of the overall effects of household extension. Model 2 excludes the vertical extension variable, and includes instead variables for the presence of extended family members who are female, employed, and disabled, testing the effects of each kind of vertically extended household member. Model 3 adds a term for the interaction between the presence of child under age five and female extended adults. (Models 2 and 3 are omitted for the Japanese sample because of the small number of Japanese extended family households.)

\section{Results}

Table 1 presents mean scores for all variables used in the analysis for each of the seven Asian ethnic groups. Immigrant women's employment rates vary by family extension as well as ethnicity - underscoring the need to disaggregate women from different Asian ethnicities. In every group, women in extended households were more likely to be employed than those in nuclear households. Filipinas had employment rates close to 80 percent, with Vietnamese and Chinese women having rates around 70 
percent. Korean and Asian Indian women had lower rates, 51 and 59 percent, respectively. Pakistani and Japanese women had the lowest rates of about 40 percent. Women in extended-family households have higher employment rates in every group, but the order of groups by employment rate is the same.

Family extension is more common among Vietnamese and Filipino women, while Korean and Japanese women are the least likely to have extended families. Within extended households, there are on average one or two extended adults and nearly 90 percent include a female extended member. Disabled extended adults are more common than those who are employed. (In results not shown, we found disabled adults are less prevalent in households having young children.)

We turn next to examining how much the difference in family characteristics, women's human capital, and labor market circumstances distinguish women in vertically extended households. Women in extended households have access to greater husband earnings (except for Asian Indian) and other family income, and they are more likely to be mothers of young children (except for Japanese and Asian Indian). Although greater household incomes and presence of young children should correspond with lower employment rates, as Table 1 shows, women in extended households have higher employment rates. Vietnamese women in particular are the most likely to have young children, notwithstanding their higher employment rate. Extended family households are more likely to be self-employed (except for Filipina and Japanese). But higher self-employment rates do not match higher employment rates, as Korean, Pakistani and Vietnamese families are more often running family businesses, but of these only Vietnamese women are likely to be employed.

Aggregate human capital characteristics do not well explain variations in employment rates across ethnic groups and between extended vs. non-extended household structures. Asian immigrant women's generally high educational attainment and varying degree of English proficiency do not parallel their employment patterns. Despite higher educational level of Asian Indian women, they are less likely to be employed than Vietnamese counterparts. Women in extended households are less educated on average, but are more likely to be employed. English proficiency does not always lead to higher employment rate, as seen in Asian Indian women who are one of the most proficient groups. Rather, duration of U.S residence is a better match, as women in extended-family households tend to have been in the U.S. longer and are more likely to be employed. Among most recent immigrants (e.g., Japanese, Asian Indian, and Filipina) who have been in the U.S less than 10 years, Filipinas show high employment rates, probably because many of them are themselves labor migrants (Parreñas 2000). Among measures of labor market structure, only ethnic concentration scores vary substantially, with Japanese recording the highest ethnic concentration (espe- cially in Hawaii). Within each group extended families tend to live in more ethnically concentrated areas.

\section{Models of employment odds}

Table 2 presents the results of logistic regression models examining how these factors are associated with women's employment for all women in the same model, and then across the seven national origin groups. Overall, the presence of vertically extended family members is positively associated with women's employment, as predicted. This finding, confirming our first hypothesis, is consistent with the older research (Stier and Tienda 1992; Tienda and Glass 1985). For Japanese, Korean, and Pakistani women, there was no significant association between the presence of extended family member and women's employment. This is consistent with hypothesis 1a, which expects ethnic variations in the overall relationship between household extension and women's employment.

Table 3 shows models for women's employment on extended household adults by gender, employment, and health status. These results are illustrated in Figure 1, which shows predicted probabilities of employment for each Asian group by the presence of female, employed, and disabled extended adults; and the results of the interaction between female adults and children under age 5 (see below).

For the combined Asian sample our hypotheses are generally supported. Female extended adults are positively associated with women's employment; the odds of employment are 45 percent higher for women with female adults in the household than for those without, consistent with hypothesis 2 . Employed adults are positively associated with women's employment; the odds of employment are 46 percent higher for women with employed adults in the household, consistent with hypothesis 3. But disabled adults show a non-insignificant association, which fails to support our hypothesis 4 .

There are variations in these patterns across national origin groups. The positive association between female extended adults and women's employment is not significant for Pakistanis. However, Figure 1 shows that with female adults in the household, the predicted probabilities of employment increase roughly 9-17 points for Chinese, Korean, Filipina, Asian Indian, and Vietnamese women. Although the association for Pakistani families is not statistically significant, all the effects are positive.

We further examine whether support for employment that results from female adults' presence may be oriented toward reducing childcare burdens associated with young children. The interaction term between the two variables is significant for the aggregate Asian group, which is consistent with hypothesis $2 \mathrm{a}$. The relationship is only statistically significant for Koreans and Vietnamese, but Figure 1 shows that the direction of the effect of female extended adults according to the presence of young children is positive for each group. Predicted probabilities of employment for mothers of young 
children who live with mothers or mothers-in-law are 16-36 points higher than those without one.

Regarding employed extended adults, the positive association holds for Filipina, Vietnamese, and Asian Indian women, while it does not hold for Chinese, Korean, and Pakistani, which is consistent with our hypothesis $3 a$, anticipating ethnic variation. Figure 1 shows that the predicted probabilities of employment increase 12-15 percentage points for Filipina, Asian Indian, and Vietnamese women with employed extended adults. Effects for the other groups are not significant at the $p<.05$ level. Although disabled adults show no statistically significant association with women's employment for the aggregate Asian group, the expected negative association was found among Koreans. This variation is consistent with hypothesis $4 \mathrm{a}$.

A few other results are noteworthy due to their relevance to previous research. The generally positive associations between women's employment and household size, and with the presence of self-employed members, do not hold for some groups. Family businesses were not associated with Filipina or Pakistani women's employment (Table 2). And larger household size is not associated with higher odds of employment for Pakistani women. Higher ethnic concentration is associated with increased odds of employment for Chinese, Japanese, and Filipina women, but decreased odds of Vietnamese women's employment.

\section{Discussion}

Our results are consistent with our hypotheses that family extension facilitates women's employment for married Asian immigrant women, and that the effect is conditional on the extended adults' family roles according to gender, employment, and health status. Female adults' positive association with employment is universal across groups, and our interaction model suggests that this results from child care assistance. (The nonsignificant interactions for some groups may result from the small number of households in our sample in which younger children and female extended adults coreside.) Extended household members with jobs are positively associated with the employment of hosting women. Although household income is controlled, it is possible that income from extended-family adults' might be allocated to help purchase child care or housekeeping services. And given immigrant women's reliance on personal ties for job-attainment (Eckstein and Nguyen 2011; see Sassen, 1995:103), extended adults' social networks might bring job opportunities, although the specific mechanisms are not captured in this analysis. Disabled adults' trivial association with lowering women's employment is an unexpected result.

The variations across national origin groups are important and may spur future research. Family extension has no association with Japanese, Korean and Pakistani women's employment, although the low proportion of extended households may help explain that, at least for Japanese and Korean women. Employed extended adults' assistance was less apparent for Chinese, Korean, and Pakistani than Asian Indian, Filipina and Vietnamese; and disabled extended adults' hindrance was only salient for Korean women.

Given Pakistani women's very low employment rates, younger age, and their tendency to arrive in the U.S. as dependent spouses (Raj and Silverman 2002), our speculation is that their empowerment is more likely to be compromised by both legal restrictions and cultural expectations of their home country. Salway (2007) reports that cultural scripts in Pakistan constrain the market employment of married women, and the presence of extended family members may reinforce this code of conduct. However, Pakistani women also may face legal constraints on employment associated with their visas (Lee, Zhou, and Kim 2013). Unfortunately, information about respondents' visa status as well as the type of visa is not available in ACS. Further research is necessary to resolve this question.

The positive association between employment and extended household members with jobs is not observed for Chinese, Korean, and Pakistani women. Interestingly, Chinese and Korean extended adults are among the least likely to have jobs, at $10 \%$ and $5 \%$ respectively. In Filipina and Vietnamese extended families, in contrast, employed adults are present in $20 \%$ and $14 \%$ of households respectively. Pakistani families present an anomalous pattern, as one in five extended households includes an employed adult, but their presence apparently does not increase Pakistani women's low levels of employment.

We cannot explain why disabled adults lower women's employment only in Korean immigrant families. For this group, however, the effect is consistent with a cultural imperative for family extension rather than an economic motivation geared toward facilitating women's employment. Extending their households to adults having disability appears to be a costly option for Korean women in terms of employment. Further research will be needed to investigate the variations here.

Finally, several patterns emerge that may be unique to some Asian immigrant women. The deterring effects of husband's earnings and other income for women's employment (except for Vietnamese) appear to be stronger than for other racial-ethnic groups, except for Vietnamese (Cohen and Bianchi 1999; England et al. 2004). Vietnamese women present an interesting comparison to Black women, among whom husband's income does not affect women's employment odds. These findings indicate women's employment decisions may be culturally patterned, but the specific forms and behaviors differ across national-origin groups. In addition, the lower likelihood of being employed when living with a high concentration of co-ethnics for Vietnamese women also may support the suggestion that jobs in the ethnic community are more geared toward men's labor than women's (Zhou 1992), or that concentrated ethnicity rein- 
forces the traditional culture of women's subordination for some groups (Min 2001; Read 2004).

\section{Conclusion}

Married Asian immigrant women's paid labor supply is more common with the presence of older adults in their homes. This is ironic to the extent that an ostensibly "traditional" practice - extended family living arrangements - encourages the "modern" practice of women's labor market participation. However, these results underscore that we cannot generalize across national origin groups about extended adults' family roles, due to heterogeneous demographic characteristics, socioeconomic status, and cultural backgrounds. Asian immigrant women's employment decisions are made through the gender, economic, and cultural negotiation within families. Hampered by housework and childcare, women apparently receive some support from their mothers or mothers-in-law generally. Faced with less favorable structure of opportunities, some women might get support from employed adults to increase market labor participation, while other groups of women do not enjoy such an advantage. Care demands for disabled adults do not play as strong a role as expected, although the burden seems to be heavy for Korean women. Thus, family extension appears not only to be an important economic strategy but also a response to social and cultural considerations that are widely different by national origins.

Certain limitations of our research are clear. The causal effects of family extension cannot be established here. For example, it could be that employed (and perhaps healthier, and wealthier) women are more likely to attract their parents (in-law. Although competing explanations cannot be resolved with cross-sectional data analysis, our controls for related control variables - including especially the disability status of host women, and other household income - lend confidence to our interpretations. Second, our measure of employment does not address the issue of occupational attainment. Espiritu (2008) posits that Asian immigrants exhibit distinctive gender dynamics according to occupational class structure. Specification of husbands' and extended family members' occupations would enhance our understanding here.

Nevertheless, our study makes three noteworthy contributions to the literature on Asian immigrant women, work, and family. First, we not only extend previous research on immigrant women's employment but also centralize the role of extended families in their lives. We distinguished seven different groups of Asian immigrant women and how their adaptation to the US economy may be facilitated or hindered by the presence of extended family members, specifically by the gender, employment and health status of those additional adults. This extends our knowledge of the implications of extended family arrangements for women in studies of immigrant families, about which we still no relatively little. Second, a methodologically refined approach is made by distinguishing the "hosts" and "guests" by householder status. Studies of household extension tend to neglect the question, "In whose home?" (Cohen and Casper 2002). In our paper, the "hosts" are married, younger generation; the "guests" are older, and moved in to live with the younger generation. By this distinction, we can illuminate the younger generation's needs or choices for extended family arrangements. Third, we use more recent data than previous research, with sample sizes large enough to provide estimates for smaller groups. This identifies important ethnic variation that deserves additional attention, including investigation of immigration histories, community structures, and cultural prescriptions. In light of increasing labor force activity among women and persisting disparities in labor force participation among immigrant women, our insight into immigrant women's diverse employment needs and constraints in relation to family roles should be useful.

\section{Note:}

${ }^{1}$ The Chronbach's alpha reliability score for the index of three care-intensive disabilities was .75 . 


\section{References}

Allard, M. D. 2011. "Asians in the U.S. labor force: Profile of a diverse population." Monthly Labor Review 134(11):3-22.

Angel, Ronald, and Marta Tienda. 1982. "Determinants of Extended Household Structure: Cultural Pattern or Economic Need?" American Journal of Sociology. 87 (6).

Anthias, Floya, and Nishi Mehta. 2003. "The intersection between gender, the family and selfemployment: the family as resource." International Review of Sociology 13(1):105-116.

Ansari, H., 2004, 'The Infidel Within' Muslims in Britain since 1800, London: Hurst

Banerjee, Pallavi. 2013. "Paradoxes of Patriarchy: Contradicting Experiences of South Asian Women in Ethnic Labor Markets". p.96-116. Immigrant women workers in the neoliberal age. Urbana: University of Illinois Press.

Becker, Gary S. 1965. "A Theory of the Allocation of Time." The economic journal: 493-517.

Berk, Sarah Fenstermaker. 1985. The gender factory: the apportionment of work in American households. New York: Plenum Press.

Brekke, Idunn. 2013. "How Do Husbands Affect the Labour Market Participation of Majority and Immigrant Women?" Journal of Ethnic and Migration Studies Journal of Ethnic and Migration Studies 39:1639-57.

Chin, Margaret M. 2013. "Changing Expectations: Economic Downturns and Immigrant Chinese Women in New York City." p. 117-130. Immigrant women workers in the neoliberal age. Urbana: University of Illinois Press.

Choi, Namkee G. 2001. Psychosocial aspects of the Asian-American experience : Diversity within diversity. New York: Haworth Press.

Chow, Esther Ngan-Ling. 1994. "Asian American Women at Work". p. 203-228. Women of color in U.S. society. Philadelphia: Temple University Press.

Choy, Catherine Ceniza. 2003. Empire of care : nursing and migration in Filipino American history. Durham: Duke University Press

Cohen, P. N. and Suzanne, M. Bianchi. 1999. "Marriage, children, and women's employment: What do we know?" Monthly Labor Review, 122(12), 22-31.

Cohen, Philip N, and Lynne M Casper. 2002. "In whose home? Multigenerational families in the united states, 1998 - 2000." Sociological Perspectives 45(1):1-20.

Cohen, Philip N. 2002. "Extended Households at Work: Living Arrangements and Inequality in Single Mothers' Employment." Sociological Forum 17(3):445-463.

Cohen, Philip N. and Jen'nan G Read. 2007. “One Size Fits All ? Explaining U . S . -born and Immigrant Women's Employment across 12 Ethnic Groups." Social Forces 85(4):1713-34.
Cooke, T J, and A J Bailey. 1996. "Family migration and the employment of married women and men." Economic geography 72(1):38-48.

Cotter, David A, Joan M Hermsen, and Reeve Vanneman. 2001. "Women's work and working women: the demand for female labor." Gender and Society 15(3):429-452.

Crozier, Gill and Jane Davies. 2006. "Family Matters: A Discussion of the Bangladeshi and Pakistani Extended Family and Community in Supporting the Children's Education." The Sociological Review 54(4):678-95.

Dallalfar, Arlene. 1994. "Iranian Women As Immigrant." Gender and Society 8(4):541-561.

Eckstein, S., and T. N. Nguyen 2011. "The Making and Transnationalization of an Ethnic Niche: Vietnamese Manicurists". International Migration Review, 45, 3.

Edin, Kathryn, and Laura Lein. 1997. Making ends meet: How single mothers survive welfare and low-wage work. New York: Russell Sage Foundation.

England, Paula, Carmen Garcia-Beaulieu, and Mary Ross. 2004. "Women's Employment among Blacks, Whites, and Three Groups of Latinas: Do More Privileged Women Have Higher Employment?" Gender and Society 18(4):494-509.

Esping-Andersen, Gøsta. The Incomplete Revolution: Adapting to Women's New Roles. Cambridge, UK; Malden, MA: Polity, 2009.

Espiritu, Yen Le. 2008. Asian American Women and Men: Labor, Laws and Love. Edited by Judith A Howard, Barbara Risman, and Joey Sprague. Lanham, Maryland: Rowman and Littlefield Publishers, Inc.

Espiritu, Yen. Le. 1999. "Gender and Labor in Asian Immigrant Families." American Behavioral Scientist 42(4):628-647.

Fernández, Raquel, and Alessandra Fogli. 2009. "Culture: An Empirical Investigation of Beliefs, Work, and Fertility." mac American Economic Journal: Macroeconomics 1(1):146-77.

Figueroa, Janis Barry, and Edwin Melendez. 1993. "The importance of family members in determining the labor supply of Puerto Rican, Black, and White single mothers." Social Science Quarterly 74(4):867883.

Flores-Gonzalez, Nilda. 2013. "Immigrant women workers in the neoliberal age." Urbana: University of Illinois Press.

Glick, J E, F D Bean, and J.Van Hook. 1997. "Immigration and Changing Patterns of Extended Family Household Structure in the United States: 1970-1990." Journal of Marriage and the Family 59:177-91.

Greenlees, Clyde S, and Rogelio Saenz. 1999. "Determinants of employment of recently arrived Mexican Immigrant wives." International Migration Review 33(2):354-377. 
Haines, David W. 1987. "Patterns in Southeast Asian Refugee Employment. A Reappraisal of the Existing Research." Ethnic groups 7(1):39-63.

Harrison, Algea O., Melvin N. Wilson, Charles J. Pine, Samuel Q. Chan, and Raymond Buriel. 1990. "Family Ecologies of Ethnic Minority Children". Child Development. 61 (2): 347-362.

Hernandez, Donald, Nancy A Denton, and Suzanne E. Macartney. 2007. "Young Hispanic Children in the 21st Century." Journal of Latinos and Education 6:209-28.

Hemmens, George C., Charles Hoch, and Jana Carp. 1996. Under one roof: issues and innovations in shared housing. Albany: State University of New York Press.

Herbst, C.M. 2010. "The Labor Supply Effects of Child Care Costs and Wages in the Presence of Subsidies and the Earned Income Tax Credit." Review of Economics of the Household 8(2), 199-230.Hipple, Steven F. 2010. "Monthly Labor Review: Selfemployment in the United States." Monthly Labor Review (September):17-32.

Immigration and Naturalization Services. 1997. Immigrationin Fiscal Year 1995 (Report No. 6). Washington, DC

Ishii-Kuntz, Masako 2000. "Diversity within Asian American Families." Pp. 274-292. in Handbook of family diversity. edited by D.H. Demo, K.R. Allen, and M.A. Fine. New York: Oxford University Press.

Jarrett, Robin L. 1994. "Living Poor: Family Life Among Single Parent , African-American Women." Social Problems 41(1):30-49.

Juhn, Chinhui, and Simon Potter. 2006. "Changes in Labor Force Participation in the United States". The Journal of Economic Perspectives. 20 (3): 27-46

Kahn, Joan R, and Leslie A, Whittington, 1996, "The Labor Supply of Latinas in the USA: Comparing Labor Force Participation, Wages, and Hours Worked with Anglo and Black Women," Population Research and Policy Review 15:45-73

Kalavar, Jyotsna. M. and John Van Willigen. 2005. "Older Asian Indians Resettled in America: Narratives about Households, Culture and Generation." Journal of Cross-Cultural Gerontology 20:213-30.

Kamo, Yoshinori. 2000. "Racial and Ethnic Differences in Extended Family Households." Sociological Perspectives 43:211-29.

Kamo, Yoshinori, and Min Zhou. 1994. "Living Arrangements of Elderly Chinese and Japanese in the United States." Journal of Marriage and Family 56(3):544-558.

Le, C. N. 2007. Asian American Assimilation: Ethnicity, Immigration, and Socioeconomic Attainment. New York: LFB Scholarly Pub..

Lee, Hee Yun, and Eaton Charissa K. 2009. "Financial Abuse in Elderly Korean Immigrants: Mixed Analysis of the Role of Culture on Perception and Help-
Seeking Intention." Journal of Gerontological Social Work 52(5):463-88.

Lee S, H. Zhou and Y. Kim. 2014. "Labor force participation among Asian immigrant women: Findings from the 2007 American Community Survey." International Journal of Social Welfare 23(3):296-308.

Leibowitz, Arleen, and Jacob Alex Klerman. 1995. "Explaining Changes in Married Mothers' Employment Over Time". Demography. 32 (3): 365.

Light, Ivan, and Steven J, Gold, 2000, Ethnic Economies. Academic Press

Long, J. E. 1980 "The Effect of Americanization on Earnings: Some Evidence for Women," Journal of Political Economy, 88 (3): 620-629.

Min, Pyong Gap. 1997. "Korean Immigrant Wives' Labor Force Participation, Marital Power, and Status." Women and work: Exploring race, ethnicity, and class 176-91.

Min, Pyong Gap. 1998. Changes and Conflicts : Korean Immigrant Families in New York. Boston: Allyn and Bacon.

Min, Pyong Gap. 2001. "Changes in Korean Immigrants' Gender Role and Social Status , and Their Marital Conflicts." New York 16(2).

Mui, Ada C. Shibusawa Tazuko. 2008. Asian American elders in the twenty-first century : key indicators of well-being. New York: Columbia University Press.

Mui, Ada C. Nguyen Duy Kang Dooyeon Dietz Domanski Margaret. 2006. "Demographic Profiles of Asian Immigrant Elderly Residing in Metropolitan Ethnic Enclave Communities." Journal of Ethnic and Cultural Diversity in Social Work 15(1/2):193-214.

Pedace R, Rohn Kumar S. 2014. "A warm embrace or the cold shoulder? Wage and employment outcomes in ethnic enclaves." Contemp. Econ. Policy Contemporary Economic Policy 32(1):93-110.

Parreñas, Rhacel. S. 2000. Migrant Filipina Domestic Workers and the International Division of Reproductive Labor. Gender and Society, 14(4):560580.

Portes, Alejandro, and Robert L. Bach. 1985. Latin journey: Cuban and Mexican immigrants in the United States. Berkeley: University of California Press.

Raj, Jay, and Anita Silverman. 2002. "Violence Against Immigrant Women: The Roles of Culture, Context, and Legal Immigrant Status on Intimate Partner Violence." Violence Against Women 8(3):367-98.

Ram, M., and R. Wong. 1994. "Covariates of Household Extension in Rural India: Change Over Time." Journal of Marriage and the Family 56:853864.

Read, Jen'nan Ghazal. 2004. "Cultural Influences on Immigrant Women's Labor Force Participation: The Arab-American Case." International Migration Review 38(1):52-77. 
Ridgeway, Cecilia L. Framed by Gender : How Gender Inequality Persists in the Modern World. New York: Oxford University Press, 2011.

Rosenbaum, Emily, and Greta Gilbertson. 1995. 'Mothers ' Labor Force Participation in New York City: A Reappraisal of the Influence of Household Extension." Journal of Marriage and the Family 57(1):243-249.

Ruggles, Steven. 1987. Prolonged Connections: The Rise of the Extended Family in Nineteenth-Century England and America. Madison, Wis.: University of Wisconsin Press.Salway, Sarah M. 2007. "Economic Activity among UK Bangladeshi and Pakistani Women in the 1990s: Evidence for Continuity or Change in the Family Resources Survey." Journal of Ethnic and Migration Studies 33:825-47.

Sanders, JM, and Victor Nee. 1996. "Immigrant selfemployment: The family as social capital and the value of human capital." American sociological review 61(2):231-249.

Sassen, S. 1995 "Immigration and Local Labor Markets.', In The Economic Sociology of Immigration: Essays on Networks, Ethnicity, and Entrepreneurship. Ed. A. Portes. New York: Russell Sage Foundation. Pp. 87-127.

Schoeni, Robert. 1998. "Labor Market Outcomes of Immigrant Women in the United States: 1970 to 1990" International Migration Review 32(1):57-77.

Slaughter, D. X, and P. Dilworth-Anderson. 1985. "Childcare of black sickle cell anemic children: Impact of father's presence and absence from households." Paper presented at the Biennial Meeting of the Society for Research in Child Development, Toronto, Canada.

Stier, Haya, and Marta Tienda. 1992. "Family, Work, and Women: The Labor Supply of Hispanic Immigrant Wives," Internationai Migration Review 26:1291-1313

Stoloff, Jennifer A, Jennifer L Glanville, and Elisa Jayne. 1999. "Women's participation in the labor force : the role of social networks." Social Networks 21:91-108.

Tienda, Marta and Jennifer Glass. 1985. "Household structure and labor force participation of Black, Hispanic, and White mothers." Demography 22(3):381-394.

Treas, By Judith. 2009. "Four Myths About Older Adults in America ' s Immigrant Families." Journal of the American Society on Aging 32(4):40-45.

Treas, Judith, and Shampa Mazumdar. 2002. "Older people in America' $s$ immigrant families Dilemmas of dependence , integration , and isolation." Journal of Aging Studies 16:243-258.

Treas, Judith, and Shampa Mazumdar. 2004. "Kinkeeping and caregiving: Contributions of older people in immigrant families." Journal of Comparative Family Studies 35:105-122.
U.S. Department of the Health and Human Services. 2009. A Statistical Profile Older of Asian Americans Aged 65+. Washington D.C. Retrieved February 2, 2015.

Van Hook J, and J E Glick. 2007. "Immigration and living arrangements: moving beyond economic need versus acculturation." Demography 44:225-49.

Waldinger, Roger, and Greta Gilbertson. 1994. "Immigrants' progress: Ethnic and Gender Differences among U.S. immigrants in the 1980s." Sociological Perspectives 37(3):431-444.

Weng S.S, Nguyen P. V. 2011. "Factors affecting elder caregiving in multigenerational Asian American families." Families in Society 92(3):329-35.

Wilson, Melvin N. 1986. "The Black extended family: An analytical consideration." Developmental Psychology 22:246-58.

Wong, Morrison G, and Charles Hirschman. 1983. "Labor Force Participation and Socioeconomic Attainment of Asian-American Women." Sociological Perspectives 26(4):423-446.

Yamanaka, Keiko, and Kent McClelland. 1994. "Earning the model-minority image: diverse strategies of economic adaptation by Asian-American women." Ethnic and Racial Studies 17(1):79-114.

Zhou, M. 1992. Chinatown: The socioeconomic potential of an urban enclave. Philadelphia: Temple University Press. 
Table1. Means of variables used in the analysis: married, first-generation Asian immigrant women

\begin{tabular}{|c|c|c|c|c|c|c|c|c|c|c|c|c|c|c|}
\hline & \multicolumn{7}{|c|}{ All Women } & \multicolumn{7}{|c|}{ Women in Vertically Extended-Family Households } \\
\hline & Chinese & Japanese & Korean & Filipina & Vietnamese & Indian & Pakistan & Chinese & Japanese & Korean & Filipina & Vietnamese & Indian & Pakistan \\
\hline Employed & 0.69 & 0.43 & 0.51 & 0.78 & 0.72 & 0.59 & 0.40 & 0.78 & 0.62 & 0.64 & 0.89 & 0.80 & 0.74 & 0.46 \\
\hline Immigrated 0-9 & 0.30 & 0.45 & 0.33 & 0.36 & 0.28 & 0.45 & 0.37 & 0.24 & 0.24 & 0.18 & 0.26 & 0.29 & 0.31 & 0.36 \\
\hline Immigrated 10-19 & 0.42 & 0.37 & 0.34 & 0.33 & 0.46 & 0.38 & 0.46 & 0.51 & 0.48 & 0.39 & 0.43 & 0.49 & 0.45 & 0.47 \\
\hline Immigrated $20+$ & 0.28 & 0.18 & 0.33 & 0.31 & 0.27 & 0.16 & 0.17 & 0.25 & 0.29 & 0.43 & 0.31 & 0.21 & 0.24 & 0.17 \\
\hline Disability & 0.02 & 0.01 & 0.02 & 0.02 & 0.04 & 0.02 & 0.04 & 0.01 & 0.00 & 0.03 & 0.02 & 0.03 & 0.03 & 0.03 \\
\hline Age & 42.77 & 40.80 & 43.74 & 42.95 & 42.33 & 38.20 & 40.26 & 40.91 & 42.29 & 44.17 & 42.45 & 39.01 & 39.34 & 38.15 \\
\hline English very well & 0.72 & 0.79 & 0.62 & 0.97 & 0.47 & 0.93 & 0.79 & 0.69 & 0.95 & 0.65 & 0.97 & 0.55 & 0.91 & 0.84 \\
\hline Less than high school & 0.14 & 0.01 & 0.05 & 0.04 & 0.40 & 0.06 & 0.16 & 0.17 & 0.05 & 0.03 & 0.02 & 0.33 & 0.08 & 0.12 \\
\hline High school graduate & 0.15 & 0.14 & 0.23 & 0.12 & 0.27 & 0.08 & 0.18 & 0.20 & 0.14 & 0.25 & 0.08 & 0.26 & 0.11 & 0.18 \\
\hline Some college & 0.13 & 0.35 & 0.20 & 0.22 & 0.20 & 0.10 & 0.16 & 0.14 & 0.33 & 0.25 & 0.20 & 0.24 & 0.15 & 0.17 \\
\hline College degree & 0.22 & 0.38 & 0.37 & 0.55 & 0.11 & 0.37 & 0.29 & 0.17 & 0.48 & 0.40 & 0.64 & 0.15 & 0.37 & 0.33 \\
\hline Advanced degree & 0.35 & 0.13 & 0.14 & 0.08 & 0.03 & 0.39 & 0.21 & 0.33 & 0.00 & 0.07 & 0.06 & 0.02 & 0.29 & 0.20 \\
\hline \multicolumn{15}{|l|}{ Local labor market } \\
\hline Unemployment rate & 9.90 & 9.75 & 9.96 & 10.17 & 9.95 & 9.82 & 9.69 & 10.05 & 9.76 & 9.96 & 10.46 & 10.08 & 10.25 & 9.99 \\
\hline Women's emp. share & 47.14 & 47.00 & 47.02 & 46.85 & 46.71 & 47.45 & 47.52 & 47.05 & 47.12 & 47.11 & 46.61 & 46.61 & 47.30 & 47.49 \\
\hline Ethnic concentration & 2.97 & 6.27 & 2.55 & 3.09 & 3.05 & 2.28 & 2.78 & 3.45 & 12.97 & 3.00 & 3.96 & 3.33 & 2.33 & 2.73 \\
\hline \multicolumn{15}{|l|}{ Family conditions } \\
\hline Household size (excl.children) & 2.49 & 2.10 & 2.39 & 2.68 & 2.76 & 2.42 & 2.83 & 3.86 & 3.67 & 3.60 & 3.93 & 3.92 & 3.88 & 4.15 \\
\hline Own children & 1.28 & 1.17 & 1.32 & 1.44 & 1.69 & 1.39 & 2.18 & 1.56 & 1.62 & 1.49 & 1.71 & 1.75 & 1.66 & 1.90 \\
\hline Any child under 5 & 0.21 & 0.27 & 0.18 & 0.20 & 0.25 & 0.33 & 0.33 & 0.33 & 0.24 & 0.19 & 0.27 & 0.40 & 0.32 & 0.39 \\
\hline Self-employment & 0.18 & 0.17 & 0.33 & 0.10 & 0.26 & 0.15 & 0.25 & 0.21 & 0.14 & 0.46 & 0.10 & 0.26 & 0.25 & 0.26 \\
\hline Husband Income (ln) & 9.53 & 10.39 & 9.22 & 8.99 & 9.14 & 10.53 & 9.94 & 9.62 & 10.50 & 9.44 & 9.56 & 9.61 & 10.46 & 10.61 \\
\hline Other income $(\ln )$ & 4.92 & 3.56 & 4.01 & 5.23 & 4.96 & 3.98 & 4.40 & 7.36 & 8.73 & 6.50 & 7.93 & 8.50 & 7.07 & 7.16 \\
\hline \multicolumn{15}{|l|}{ Extended $\mathrm{HH}$ variables } \\
\hline Vertically Extended adult ${ }^{a}$ & 0.11 & 0.01 & 0.04 & 0.14 & 0.14 & 0.10 & 0.11 & 1.00 & 1.00 & 1.00 & 1.00 & 1.00 & 1.00 & 1.00 \\
\hline Male adult & 0.06 & 0.00 & 0.01 & 0.05 & 0.07 & 0.06 & 0.06 & 0.55 & 0.38 & 0.28 & 0.38 & 0.48 & 0.56 & 0.53 \\
\hline Female adult & 0.10 & 0.01 & 0.04 & 0.12 & 0.12 & 0.09 & 0.10 & 0.90 & 0.86 & 0.92 & 0.89 & 0.83 & 0.87 & 0.89 \\
\hline Employed adult & 0.01 & 0.00 & 0.00 & 0.03 & 0.02 & 0.01 & 0.02 & 0.10 & 0.05 & 0.05 & 0.20 & 0.14 & 0.13 & 0.20 \\
\hline Care-Intensive adult & 0.03 & 0.00 & 0.01 & 0.05 & 0.05 & 0.03 & 0.06 & 0.27 & 0.19 & 0.32 & 0.35 & 0.34 & 0.34 & 0.50 \\
\hline$N$ & 11,395 & 1,969 & 4,359 & 8,230 & 4,347 & 11,770 & 1,164 & 1,269 & 21 & 189 & 1139 & 617 & 1156 & 153 \\
\hline
\end{tabular}

Note: a: Vertically extended household contain parents (in-law) of the (spouse of) householder. Horizontally extended household contain siblings (in-law). 
Table 2. Logistic regression results for women's employment in all households: the presence of extended adult (odds ratios)

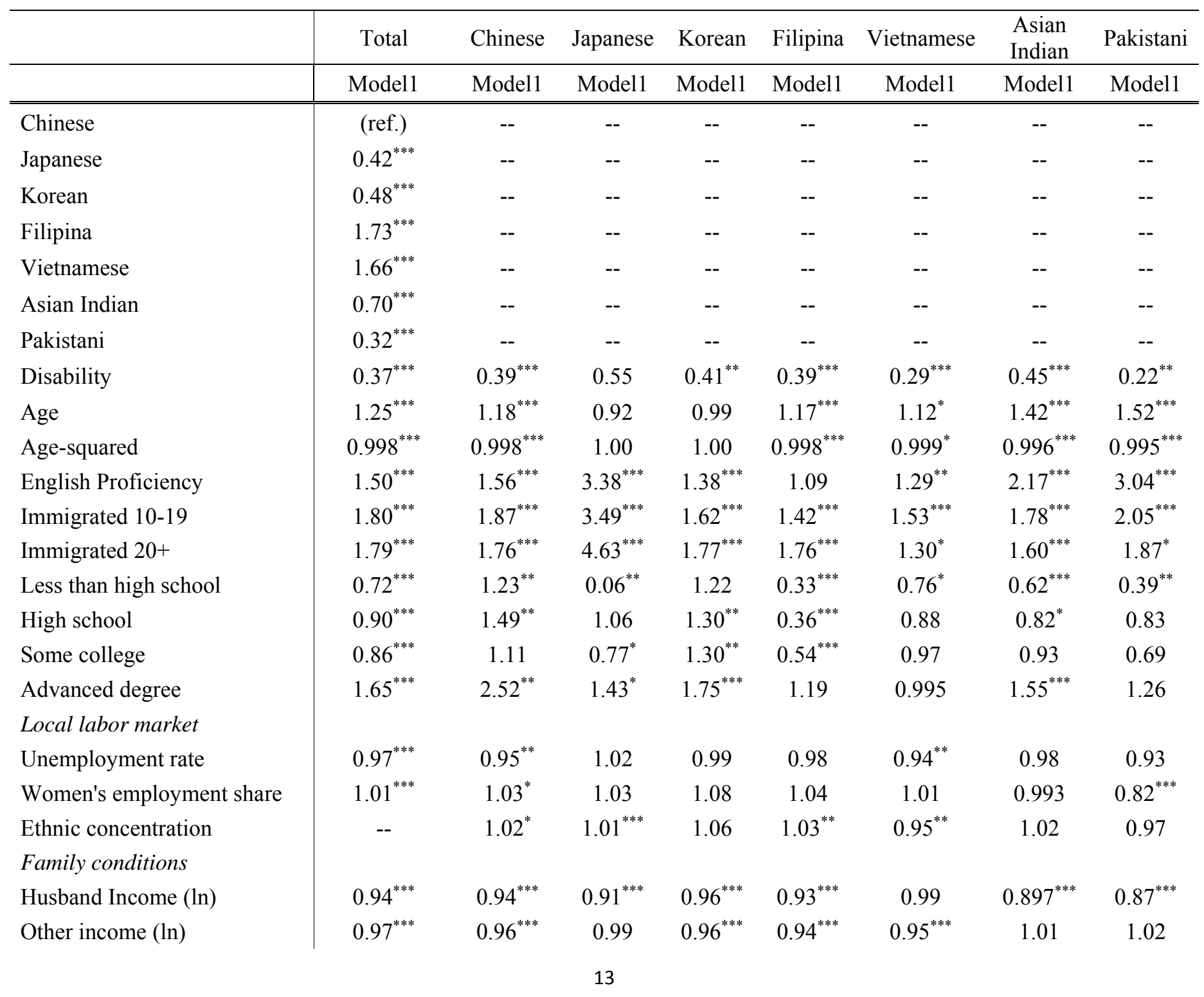




\begin{tabular}{l|cccccccc} 
Self-employment family & $1.59^{* * *}$ & $1.68^{* * *}$ & $2.13^{* * *}$ & $2.16^{* * *}$ & 0.86 & $1.68^{* * *}$ & $1.37^{* * *}$ & 0.99 \\
Number of own children & $0.82^{* * *}$ & $0.81^{* * *}$ & $0.69^{* * *}$ & $0.88^{* *}$ & $0.84^{* * *}$ & $0.87^{* *}$ & $0.77^{* * *}$ & $0.73^{* * *}$ \\
Presence of child under 5 & $0.74^{* * *}$ & $0.79^{* * *}$ & $0.54^{* * *}$ & $0.53^{* * *}$ & $0.70^{* * *}$ & $0.58^{* * *}$ & $0.86^{* *}$ & $0.56^{* *}$ \\
Household size (excl.children) & $1.33^{* * *}$ & $1.40^{* * *}$ & $1.63^{* *}$ & $1.33^{* * *}$ & $1.55^{* * *}$ & $1.26^{* * *}$ & $1.19^{* * *}$ & 1.12 \\
Vertical extension & $1.52^{* * *}$ & $1.34^{* *}$ & 1.07 & 1.21 & $1.72^{* * *}$ & $1.63^{* *}$ & $1.58^{* * *}$ & 1.09 \\
\hline$N$ & 43,234 & 11,395 & 1,969 & 4,359 & 8,230 & 4,347 & 11,770 & 1,164 \\
Likelihood ratio $\chi^{2}($ d.f $=20)$ & $5485.30(25)$ & 1211.07 & 518.13 & 615.09 & 790.23 & 308.17 & 1714.87 & 276.40 \\
AIC & 68417.59 & 16999.33 & 2688.04 & 6043.59 & 8713.91 & 5142.57 & 16118.41 & 1551.44
\end{tabular}

Note: ${ }^{* * *}: p<0.001, * *: p<0.01, *: p<0.05$ 
Table 3. Logistic regression results for women's employment: characteristics of extended adult (odds ratios)

\begin{tabular}{|c|c|c|c|c|c|c|c|c|c|c|c|c|c|c|}
\hline & \multicolumn{2}{|c|}{ All Groups } & \multicolumn{2}{|c|}{ Chinese } & \multicolumn{2}{|c|}{ Korean } & \multicolumn{2}{|c|}{ Filipina } & \multicolumn{2}{|c|}{ Vietnamese } & \multicolumn{2}{|c|}{$\begin{array}{l}\text { Asian } \\
\text { Indian }\end{array}$} & \multicolumn{2}{|c|}{ Pakistani } \\
\hline & Model2 & Model3 & Model2 & Model3 & Model2 & Model3 & Model2 & Model3 & Model2 & Model3 & Model2 & Model3 & Model2 & Model3 \\
\hline Female adult & $1.45^{* * *}$ & $1.30^{* * *}$ & $1.31^{*}$ & 1.21 & $2.13^{* *}$ & 1.59 & $1.58^{* *}$ & $1.55^{*}$ & $1.46^{* *}$ & 1.12 & $1.49^{* *}$ & $1.35^{*}$ & 0.93 & 0.84 \\
\hline $\begin{array}{l}\text { Female } \\
\text { adult*Child }<5\end{array}$ & -- & $1.34^{* *}$ & -- & 1.23 & -- & $2.41^{* *}$ & -- & 1.07 & -- & $1.76^{*}$ & -- & 1.28 & -- & 1.42 \\
\hline Employed adult & $1.46^{* *}$ & $1.41^{* *}$ & 0.89 & 0.88 & 0.43 & 0.42 & $1.67^{*}$ & 1.66 & $2.37^{*}$ & $2.27^{*}$ & 1.48 & 1.43 & 1.49 & 1.42 \\
\hline Disabled adult & 0.94 & 0.98 & 1.002 & 1.04 & $0.32^{* *}$ & $0.38^{*}$ & 1.05 & 1.06 & 0.95 & 1.03 & 1.02 & 1.06 & 1.06 & 1.09 \\
\hline$N$ & 43,234 & 43,234 & 11,395 & 11,395 & 4,359 & 4,359 & 8,230 & 8,230 & 4,347 & 4,347 & 11,770 & 11,770 & 1,164 & 1,164 \\
\hline $\begin{array}{l}\text { Likelihood ratio } \\
\left.\chi^{2} \text { (d.f. }=22\right)\end{array}$ & $6452.33(27)$ & $\begin{array}{c}6462.64 \\
(28)\end{array}$ & 1101.96 & 1103.45 & 628.33 & 887.49 & 792.43 & 792.50 & 311.31 & 316.20 & 1715.33 & 1717.52 & 276.77 & 277.22 \\
\hline AIC & 56926.51 & 56926.51 & 14199.61 & 14199.61 & 6043.59 & 6043.59 & 8713.91 & 8713.91 & 5142.58 & 5142.58 & 16118.41 & 16118.41 & 1551.44 & 1551.44 \\
\hline
\end{tabular}

Note: Japanese women in extended households are excluded from Model 2 and 3 because of a small sample size less than 30.

$* * *: p<0.001, * *: p<0.01, *: p<0.05$ 
Figure 1. Predicted probabilities of Asian immigrant women's employment by gender, employment, and disability status of extended adults

Chinese

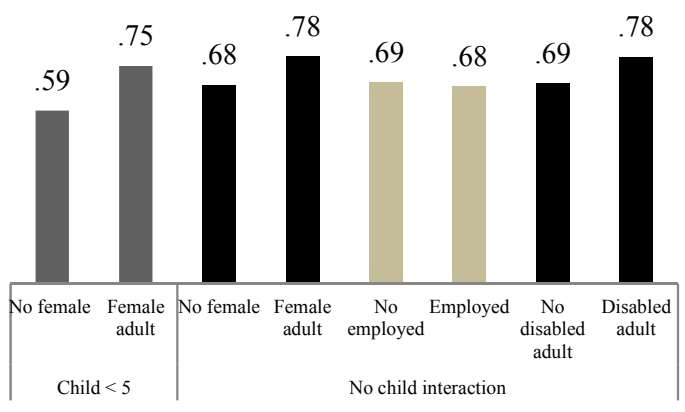

Asian Indian

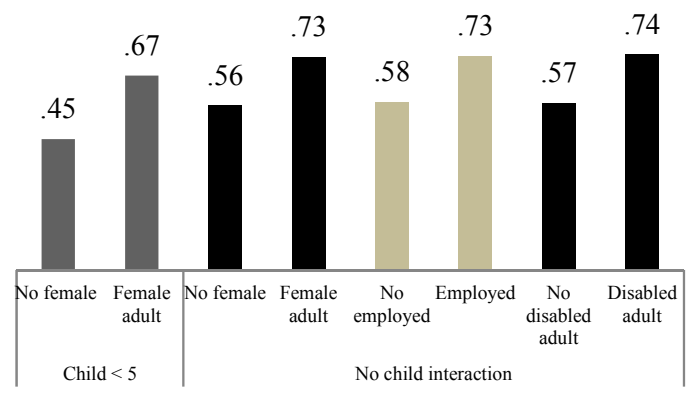

Filipina

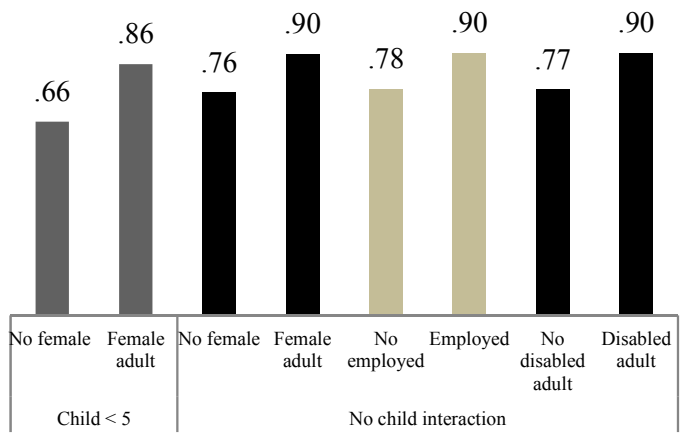

Korean

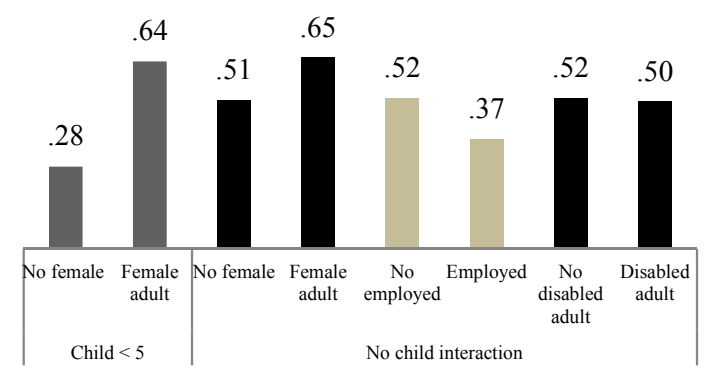

Pakistani

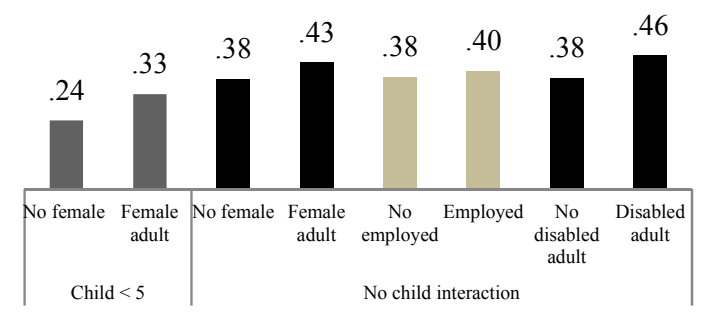

Vietnamese

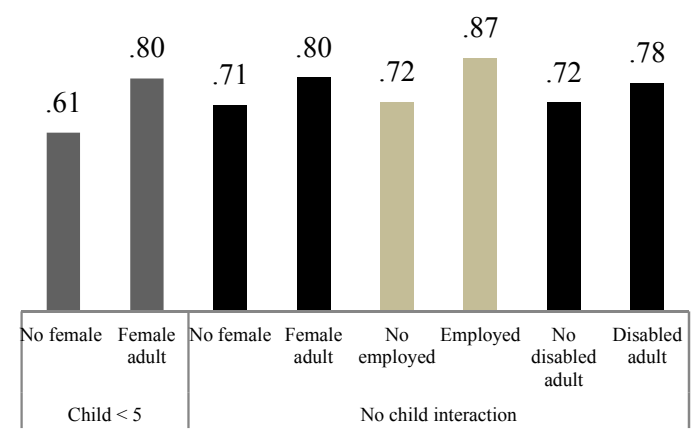

Notes: Based on Model 2 that includes extended adults' characteristics as well as all control variables; and Model 3 that adds interaction between presence of children under age 5 and the presence of female adults. All regression models weighted using ACS 2009-2011 3-year PUMS person weights. 